\title{
CLONING TWO PepT1 cDNA FRAGMENTS OF COMMON CARP, CYPRINUS CARPIO (ACTINOPTERYGII: CYPRINIFORMES: CYPRINIDAE)
}

\author{
Teresa OSTASZEWSKA ${ }^{1 *}$, Iwona SZATKOWSKA ${ }^{2}$, Tiziano VERRI ${ }^{3}$, Konrad DABROWSKI $^{4}$, \\ Alessandro ROMANO ${ }^{3}$, Amilcare BARCA $^{3}$, Magdalena MUSZYŃSKA ${ }^{2}$, Andrzej DYBUS ${ }^{2}$, \\ Piotr GROCHOWSKI ${ }^{1}$, and Maciej KAMASZEWSKI ${ }^{1}$ \\ ${ }^{1}$ Division of Ichthyobiology and Fisheries, Faculty of Animal Science, Warsaw University of Life Sciences, \\ Warsaw, Poland \\ ${ }^{2}$ Division of Molecular Cytogenetics, Faculty of Biotechnology and Animal Science, West Pomeranian University of \\ Technology, Szczecin, Poland \\ ${ }^{3}$ Laboratory of General Physiology, Department of Biological and Environmental Sciences and Technologies, \\ University of Salento, via Provinciale Lecce-Monteroni, Lecce, Italy \\ ${ }^{4}$ School of Environment and Natural Resources, Ohio State University, Columbus, Ohio, USA
}

Ostaszewska T., Szatkowska I., Verri T., Dabrowski K., Romano A., Barca A., Muszyńska M., Dybus A., Grochowski P., Kamaszewski M. 2009. Cloning two PepT1 cDNA fragments of common carp, Cyprinus carpio (Actinopterygii: Cypriniformes: Cyprinidae). Acta Ichthyol. Piscat. 39 (2): 81-86.

Background. Common carp, Cyprinus carpio, is a model organism within Teleostei. Oligopeptides are a new and promising alternative source of amino acids in animal as well as in human nutrition. In common carp, the membrane protein that transports oligopeptides across the enterocyte membrane is encoded by the gene PepT1 (SLC15A1). The aim of this paper was to sequence the PepT1 (SLC15A1) in common carp.

Materials and Methods. Intestine samples were isolated from six-week old common carp. Total RNA was isolated using a Trizol method. Reverse transcription was used to synthesize cDNA. Two different pairs of primers were designed, according to the zebrafish (Danio rerio) PepT1 sequence, and used for PCR. The amplified DNA was isolated by electrophoresis, cloned (pCRII-TOPO vectors), sequenced, and subjected to in silico analysis.

Results. Two nucleotide fragments of the PepT1 gene were obtained and analyzed using bioinformatic tools. Both fragments showed a high degree of homology with the known PepT1 genes of other teleosts, mammals, and birds. High homology of the PepT1 gene, and similar primary protein structure among the aforementioned taxa probably reflects the conservative function of the PepT1 protein product. Both fragments of the PepT1 gene were deposited in GenBank (FJ556590; FJ529670).

Conclusions. The sequenced fragments of the common carp PepT1 gene will allow evaluation of PepT1 expression in the intestines of fish fed diets containing various forms of protein, which is an issue of importance regarding fish nutrition and its import for aquaculture.

Keywords: Cyprinus carpio, peptide transporter, PepT1, intestine, sequence

\section{INTRODUCTION}

In genome sequencing of prokaryotes and eukaryotes two strategies are applied. The first, involves sequencing the entire genome. The second, and less common, approach involves sequencing specific parts of the genome, usually a single gene. However, irrespective of the strategy applied, the selection of organisms for genomic research is a most important task. The most commonly applied criterion regulating such selection, besides that of "model organism" (e.g., mouse, or rat), is consideration of the biological and commercial importance of an organism, a consideration aimed at guaranteeing that the genomic results would be practically applied. This criterion is relevant to common carp (Cyprinus carpio), for which small sections of nuclear and mitochondrial genomes have been sequenced, but for which specifics regarding genome structure, regulation of gene expression, and molecular determination of features relevant to

\footnotetext{
* Correspondence: Prof. dr hab. Teresa Ostaszewska, Pracownia Ichtiobiologii i Rybactwa, Wydział Nauk o Zwierzętach, Szkoła Główna Gospodarstwa Wiejskiego, ul. Ciszewskiego 8, 02-787 Warszawa, Poland, phone: +48 22593 6641, fax: +48 22593 6646, e-mail: teresa_ostaszewska@sggw.pl
} 
commercial interest still need to be elucidated. Therefore, partial sequencing of the common carp PepT1 gene (called also SLC15A1 - SoLute Carrier 15 A1), coding for an oligopeptide membrane transporter protein was assumed meaningful for some reasons: its expression is related to digestive tract differentiation and development, digestion physiology, and nutrient transport. Up to now the PepT1 sequences were described among other fish: zebrafish, Danio rerio (see: Verri et al. 2003), icefish, Chionodraco hamatus (see: Maffia et al. 2003), and Atlantic cod, Gadus morhua (see: Amberg et al. 2008). These issues are of key importance for optimization of stocking material pre-rearing technique development. With the above in mind, we herein report research findings from a study designed to sequence the PepT1 (SLC15A1) in common carp.

\section{MATERIALS AND METHODS}

PCR-based cloning of cDNA fragments encoding for carp PepT1. Common carp intestine was isolated from 6-week-old fish (5 individuals) killed by overdose immersion in the anaesthetic 3-aminobenzoic acid ethyl ester (MS-222 Sigma-Aldrich, Poznań, Poland). Following euthanasia, the entire length of the intestine was removed. Tissue was briefly rinsed in ice-cold saline solution $(1.1 \%$ $\mathrm{NaCl}$ ), immediately fixed in RNA later (Ambion, Inc., Austin, TX, US), and stored at $-80^{\circ} \mathrm{C}$ until use.

Total RNA was extracted from the RNAlater-stored intestine using Trizol Reagent (Invitrogen, Carlsbad, CA, US) according to the manufacturer's instructions. Reverse transcription was performed at $50^{\circ} \mathrm{C}$ for $60 \mathrm{~min}$ using SuperScript III First-Strand Synthesis System for RT-PCR (Invitrogen, Carlsbad, CA, US), oligo(dT) ${ }_{12-18}$ primer and $5 \mu \mathrm{g}$ total RNA following the manufacturer's instructions. Two microliters of resulting cDNA product was used to perform PCR with Platinum Taq DNA polymerase (Invitrogen, Carlsbad, CA, US) in the presence of zebrafish-specific primer pairs designed according to the nucleotide sequence of zebrafish PepT1 cDNA (zfpept1; GenBank acc. no. AY300011) (Verri et al. 2003). Two different primer pairs were synthesized commercially (Proligo France SAS, Paris, France) and used to amplify and clone two conserved fragments of carp PepT1 cDNA. The primer pair zfPepT1F1 (5'-TGTATCTGTC-TATAGTGTAC-3', identical to nucleotides 387-406 of zebrafish PepT1 cDNA) - zfPepT1R1 (5'-CAAATGCT-
-GCCACACAC-3', the reverse complement of nucleotides 556-572 of zebrafish PepT1 cDNA) was expected to amplify a $187 \mathrm{bp}$ fragment and the primer pair zfPepT1F2 (5'-TCAGTTTGAAGATCACCAGG-3', identical to nucleotides 580-599 of zebrafish PepT1 cDNA) - zfPepT1R2 (5'-AGTATAGGGTTCAC-GATCTG-3', the reverse complement of nucleotides 1109-1128 of zebrafish PepT1 cDNA) was expected to amplify a $549 \mathrm{bp}$ fragment. After a denaturing step at $94^{\circ} \mathrm{C}$ for $2 \mathrm{~min}, \mathrm{PCR}$ amplification was carried out for 35 cycles, with denaturation at $94^{\circ} \mathrm{C}$ for $30 \mathrm{~s}$, annealing at $50^{\circ} \mathrm{C}$ for $60 \mathrm{~s}$, and extension at $72^{\circ} \mathrm{C}$ for $60 \mathrm{~s}$, and a final extension at $72^{\circ} \mathrm{C}$ for $7 \mathrm{~min}$. RT-PCR products were separated by electrophoresis on a $1 \%$ agarose gel and stained with ethidium bromide. PCR amplification products of the expected size were eluted using the QIAquick Gel Extraction kit (Qiagen, Chatsworth, CA, US) and subsequently cloned in the pCRII-TOPO vector (TOPO TA Cloning, Invitrogen Carlsbad, CA, US). The plasmid clones containing the isolated cDNA fragments were sequenced using universal primers.

In silico analysis. The identity of cDNA fragments were confirmed by BLAST comparison with the GenBank database on the NCBI server (http://www.ncbi.nlm.nih.gov/BLAST). Partial carp PepT1 amino acid sequences were deduced using the ORF finder program at NCBI website (www.ncbi.nlm.nih.gov). Pairwise and multiple sequence alignments were carried out using the ClustalW program (http://www.ebi.ac.uk/clustalw). GenBank accession numbers for sequence comparisons were: human, Homo sapiens PepT1 (AAB61693; Liang et al. 1995), rabbit, Oryctolagus cuniculus PepT1 (AAA17721; Fei et al. 1994), rat, Rattus norvegicus PepT1 (BAA09318; Miyamoto et al. 1996), mouse, Mus musculus PepT1 (AAF81666; Fei et al. 2000), sheep, Ovis aries PepT1 (AAK14788; Pan et al. 2001), pig, Sus scrofa PepT1 (AAO43094; Klang et al. 2005), dog, Canis lupus familiaris PepT1 (AAL67837; MadinDarby canine kidney cell), chicken, Gallus gallus PepT1 (AAK39954; Chen et al. 2002), turkey, Meleagris gallopavo PepT1 (AAO16604; Van et al. 2005), zebrafish, Danio rerio PepT1 (AAQ65244; Verri et al. 2003), icefish, Chionodraco hamatus PepT1 (AAO39705; Maffia et al. 2003), and Atlantic cod, Gadus morhua PepT1 (AY921634; Rønnestad et al. 2007).

Table 1

Nucleotide sequence of the first fragment of common carp, Cyprinus carpio, PepT1 gene divided into codons, and inferred primary protein structure

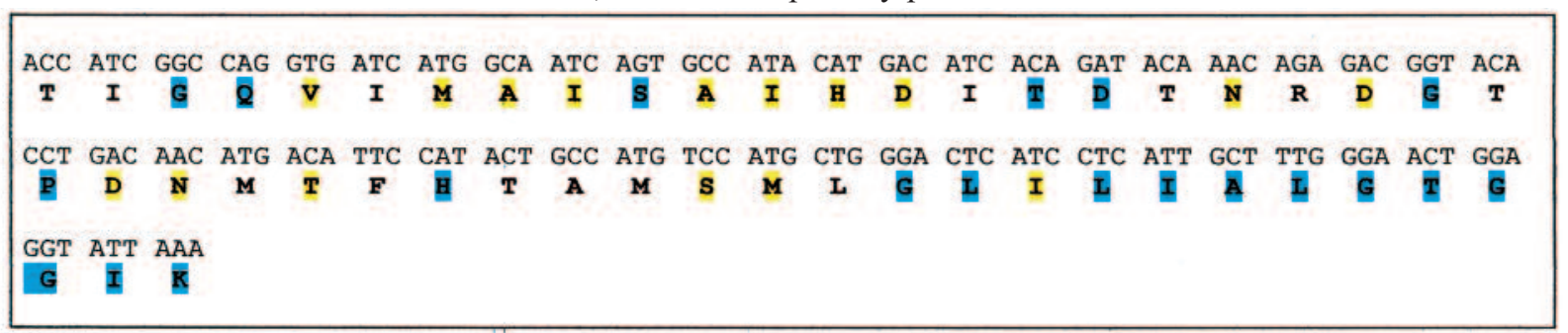

Yellow— conservative sequences among fish species of PepT1 gene; Blue — conservative sequences among vertebrate species of PepT1 gene. 
Nucleotide sequence of the second fragment of common carp, Cyprinus carpio, PepT1 gene divided into codons, and inferred primary protein structure

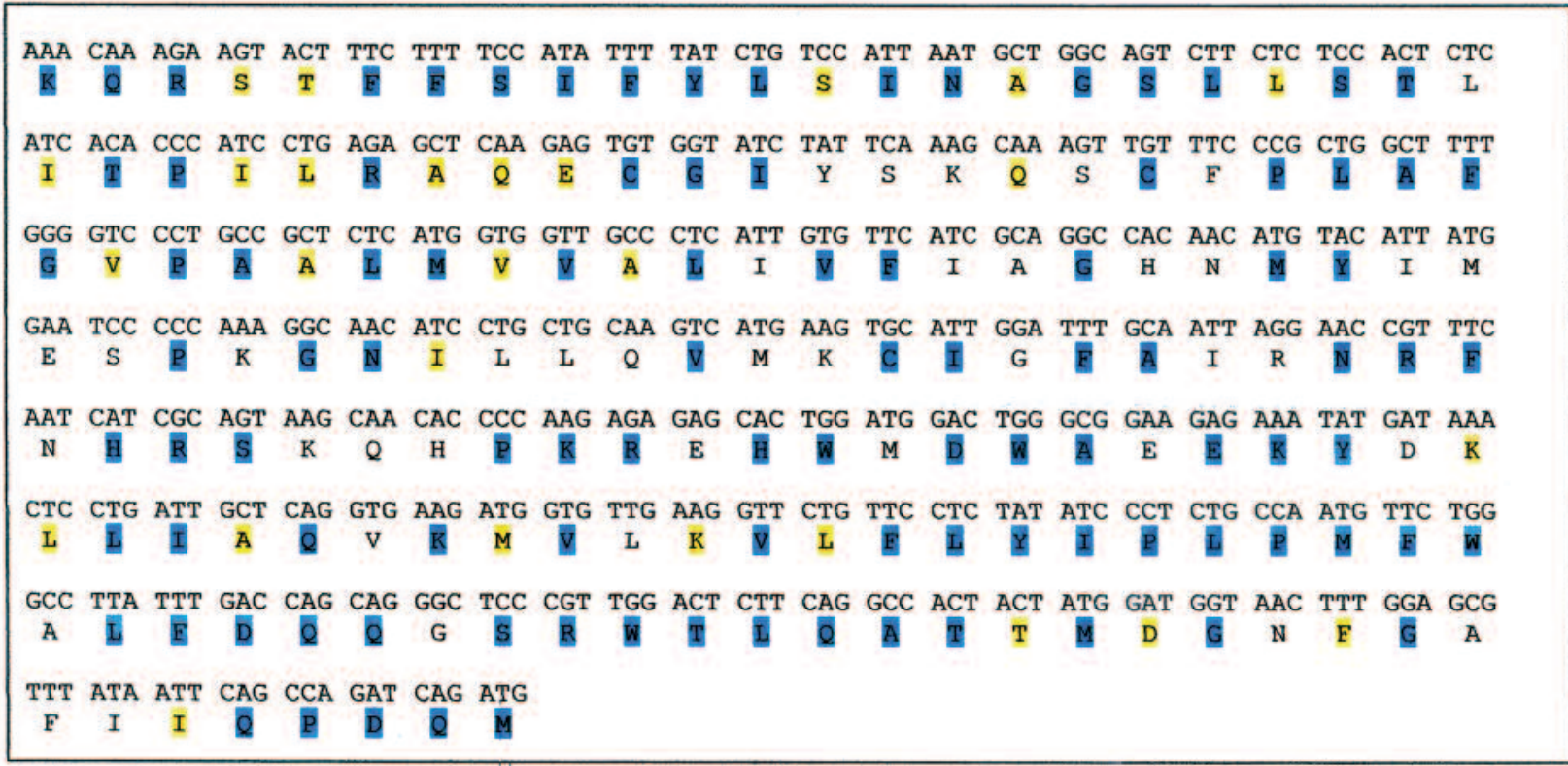

Yellow-conservative sequences among fish species of PepT1 gene; Blue—conservative sequences among vertebrate species of PepT1 gene.

The partial nucleotide sequences of the carp PepT1 exhibited highest sequence similarity to the zebrafish PepT1. In particular, the first cDNA gene fragment sequence exhibited $84 \%$ similarity to zfPepT1 and over $64 \%$ with respect to the three teleosts for which sequences were made available (Table 3).

Table 3

Similarities of common carp, Cyprinus carpio, PepT1 gene sequences vs. other vertebrate PepT1 gene sequences (zebrafish, teleosts, birds and mammals) regarding gene nucleotides and amino acids they code for

\begin{tabular}{|c|c|c|c|c|}
\hline \multirow[b]{2}{*}{ Species } & \multicolumn{2}{|c|}{ Common carp PepT1 fragment 1} & \multicolumn{2}{|c|}{ Common carp PepT1 fragment 2} \\
\hline & $\begin{array}{c}\text { similarity of nucleotides } \\
{[\%]}\end{array}$ & $\begin{array}{c}\text { similarity of amino } \\
\text { acids [\%] }\end{array}$ & $\begin{array}{c}\text { similarity of nucleotides } \\
{[\%]}\end{array}$ & $\begin{array}{c}\text { similarity of amino acids } \\
{[\%]}\end{array}$ \\
\hline Zebrafish (Danio rerio) & 84 & 86 & 87.5 & 92 \\
\hline Teleost fishes $(3 \text { species })^{\mathrm{a}}$ & 64.5 & 73.5 & 63.5 & 76.5 \\
\hline Birds $(2 \text { species })^{\mathrm{b}}$ & 96.5 & 98 & 97.5 & 97.5 \\
\hline Mammals (7 species) ${ }^{c}$ & 63 & 52 & 63 & 80.5 \\
\hline All species (13) & 41.5 & 42 & 46 & 56 \\
\hline
\end{tabular}

${ }^{a}$ zebrafish, Danio rerio; icefish, Chionodraco hamatus; Atlantic cod, Gadus morhua; ${ }^{b}$ chicken, Gallus gallus; turkey Meleagris gallopavo; 'human, Homo sapiens; rabbit, Oryctolagus cuniculus; rat, Rattus norvegicus; mouse, Mus musculus; sheep, Ovis aries; pig, Sus scrofa; dog, Canis lupus familiaris.

\section{RESULTS}

Two PepT1 cDNA fragments from common carp were cloned, sequenced and translated into their potential amino acid sequence (Tables 1, 2).

Equally high similarity at the DNA level is also observed for mammals and birds; however, only two species of the latter were compared. Inferred amino acid sequences from this fragment spanned from transmembrane domain 3 (TM 3) to TM 4 and exhibited very high (86\%) similarity to the zebrafish PepT1 amino acid sequence (Tables 2, 4). The same refers to the taxa mentioned above.
Similarly, the second cDNA fragment exhibited $87.5 \%$ similarity to the zfPepT1 gene fragment and $63.5 \%$ similarity among the teleosts. High level of homology of this fragment was observed also in GenBank PepT1 sequences for birds and mammals, 97.5 and $63 \%$, respectively (Tables 2, 3). The inferred amino acid sequence from this fragment spanned from TM 5 to the start of TM 8 and exhibited $92 \%$ similarity to the zebrafish PepT1 amino acid sequence (Table 5), 76.5\% among other fish, bird (97.5) and mammal (80.5) species. 
Comparison of amino acid sequence of PepT1 protein for various vertebrates available from the GenBank database-fragment 1

\begin{tabular}{|c|c|c|c|}
\hline human & 89 & IVYTIGQAVTSVSS INDL TD HNHDGTPDSLPVHVVLSL I GL AL I ALGTGGIKPCV & 143 \\
\hline rabbit & 89 & IVYTIGQAVTSLSSVNEL TDNNHD GTPDSLPVHVAVCM I GLLL I ALGTGGIKPCV & 143 \\
\hline rat & 89 & IVYTIGQAVISVSSINDL TDHDHDGSPNNLPLHVALSMI GL AL IALGTGGIKPCV & 143 \\
\hline mouse & 89 & IVYTIGQAVISVSS INDL TD HDHNGSPDSLPVHVALSKVGL AL I ALGTGGIKPCV & 143 \\
\hline sheep & 89 & IVYTIGQVVI AVSS INDL TDFNHD GTPNNISVHVALSM I GLVL IALGTGGIKPCV & 143 \\
\hline pig & 89 & IVYTIGQVVMAVSSINDL TDFDHNGTPNSMSVHVALSMIGLAL IALGTGGIKPCV & 143 \\
\hline dog & 89 & IVYTIGQAVTAVSSINDL TD YNKD GTPDNLSVHVALSMI GL AL IALGTGGIKPCV & 143 \\
\hline chicken & 95 & IVYTIGOAVMAVSSINDMTD ONRD GNPDNIAVH I ALSMTGL IL IALGTGGIKPCV & 149 \\
\hline turkey & 95 & IVYTIGQAVMA ISS INDMTD QNRD GNP DNIAVH I ALSVT GL IL I ALGTGGIKPCV & 149 \\
\hline zebrafish & 96 & IVYTIGQVIMA ISA I HD ITD ANRD GKPDNKTL ISLSWL GL IL IALGTGGIKPCV & 150 \\
\hline icefish & 15 & IVYMLGQUVHA IS A IHDL TD ANMD GTPDNMTLHVALSHVGL IL IALGTGGIKPCV & 69 \\
\hline at lantic cod & 96 & IVYTLGQVVMA ISA IHD ITD ANKD GTPDNMTF HVALSNVGL IL IALGTGGIKPCV & 150 \\
\hline carp & 1 & ---TIGQV IMA ISA IHD ITD TNRD GTPDNMTFHTAMSNL GL IL IALGTGGIK--- & 49 \\
\hline
\end{tabular}

Yellow-conservative sequences among fish species of PepT1 gene; Blue—conservative sequences among vertebrate species of PepT1 gene.

Table 5

Comparison of amino acid sequence of PepT1 protein for various vertebrates available

from the GenBank database-fragment 2

\begin{tabular}{|c|c|c|c|}
\hline & & $\leftrightarrow--\infty-\infty-\infty$ & \\
\hline human & 154 & GQEKQRNRFFSIFYLA INAGSLLSTI ITPMLRVQQCGIHSKQACYPLAFGVPAAL & 208 \\
\hline rabbit & 154 & GQEKQRNRFFS IF YLA INA GSLLSTIITPMVRVQQCG IHVKQACYPLAFGIPAIL & 208 \\
\hline rat & 154 & GQEKORNRFF S IFYLA INA GSLLSTIITP ILRVQQCGIHSQQACYPLAF GVP AAL. & 208 \\
\hline mouse & 154 & GQEKQRNRFFS IF YLA INGGSLLSTIITP IL RVQQCG IHSQQACYPLAF GVP AAL & 208 \\
\hline sheep & 154 & GQEKQRNRF F S IF YL A INA GSLLST I ITP ML RVQVCG IHSKQACYPL AF GVP AAL & 208 \\
\hline pig & 154 & GQEKQRNRFFS IF YL A INA GSLLSTIITPMLRVQQCG IHSTQA YPLAF GVP AAL & 208 \\
\hline dog & 154 & GQEKORNRF F S IF YL A INA GSL IST IVTP ML RVHECGIYSQRACYPL AF GVP AAL & 208 \\
\hline chicken & 160 & HQEKQRSRFFS IF YLS IN M GSL IST I ITP ILR AQE CGIHSRQQC YPLAF GVP WAL & 214 \\
\hline turkey & 160. & HOEKORSRFF IF YLS INA GSL ISTVI TP ILR AQECG IHSROQC YPL AF GVP LAL & 214 \\
\hline zebrafish & 161 & HQEKQRSTFFS IF YLS IN AGSLLSTL ITP ILRSQECGIYAKOS Y Y LAF GVP AAL & 215 \\
\hline icefish & 80 & HQEKQRSTFFS IF YLS INAGSLLSTV ITP ILRAQECGINTK OSCYPLAFGVP AAL & 134 \\
\hline a. cod & 161 & HQEKQRSTFFS IFYLS INAGSLLSTI ITP ILRAQECGIYSQOKCYPLAF GVPAAL & 215 \\
\hline carp & 1 & 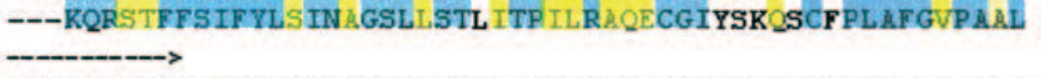 & 52 \\
\hline human & 209 & HAVAL IVFVLGSGMYKKF KPQGN IMGKV AKC IGF A I KNRF RHRSKAFPKREHWLD & 263 \\
\hline rabbit & 209 & IHAVSL IVF I I GSGMYKKF KPQGNILSKVVKC ICF A IKNRF RHRSKOF PKRAHWLD & 263 \\
\hline rat & 209 & HAV AL IVFVL GSGMYKKF QPQGNIMGKV AKC IRF A IKNRF RHRSKAF PKRNHULD & 263 \\
\hline mouse & 209 & HAV AL IVFVL GSGMYKKFQPQGNIMGKV AKC IGF IIKNRF RHRSKAYPKREHULD & 263 \\
\hline sheep & 209 & ILVSL IVFVIGSGMYKKVQPQGNIMSKV ARC IGF IIKNR ISHRSKKF P KREHULD & 263 \\
\hline pig & 209 & IHAVSL IVF VMGSRMYKKL KPQGNVMAKVVKC IGF I IKNRF RHRSKKF P KREHWLD & 263 \\
\hline dog & 209 & HAVSL IVFVI GSGMYKKFQPQGNVHGKVVKC IGF LLKNRFRHRSKQFPKREHWLD & 263 \\
\hline chicken & 215 & MAVSLVVF I A GSGMYKKVQPQGNIMVRVCKCIGF A I KNRF RHRSKEYPKREHWLD & 269 \\
\hline turkey.... & 215 & MAUSL IVF I A GSGMYKKVQPQ GNIUVQVCKC IGF I IKNRF RHRSKEYPKREHULD & 269 \\
\hline zebrafish & 216 & MVV AL IVFVI GHKMY IMESP KGNILLQV INC I GF ALNNRF RHRGKQYP KRE HWMD & 270 \\
\hline icefish & 135 & MVV ALVVF ILGSRUY IKTPPQGNI UVKVCTC IGF AVKNRF RHRSSQYPKRAHULD & 189 \\
\hline a. cod & 216 & IVVAL IVF IVGSRMYTKVAP KGN I MLEV CKC I WYAVKNRF RNRSSS IPKREHUMD & 270 \\
\hline $\operatorname{carp} \mathbf{f 2}$ & 53 & $\begin{array}{l}\text { MVVAL IVF I A GHNMY IMESP KGN ILLQUMKC IGF A IRNRFNHRSKQHP KRE HWMD } \\
\langle->\end{array}$ & 107 \\
\hline human & 264 & WAKEKYDERL, TSQIKUVTRVMFLY YPLPYFWALFDQQGSRUTLOATTMSGKIGAL & 318 \\
\hline rabbit & 264 & WAKE KYDERL I AQIKMVTRVLF L Y IPLP IFF WAF DQQGSRWTL QA TTMSGRIGIL & 318 \\
\hline rat & 264 & WAKE KYDERL ISQIK IMTKVMF L Y IPLP WF WALF DQQGSRWTL QATTHTGKIGTI & 318 \\
\hline mouse & 264 & WAKE KYDERL ISQIKIVTKVMF LF IPLP MF WGLF DQQGSRWTLQATTMNGKIGAN & 318 \\
\hline sheep & 264 & WASEKYDERL ISQIKIVTRVMF L YPLPMFWALFDQQGSRWTLQATTMSGKIGII & 318 \\
\hline pig & 264 & WAKE KYDERL ICQIKUV TRVMF L Y IPLP MF WALFDQQGSRWTLQATTMNGQIGLL & 318 \\
\hline dog & 264 & ШAKE K PDERL ISQIKMV TKVMF LY IPLP MF WALF DQQGSRWTLQATANSGKIGLL & 318 \\
\hline chicken & 270 & WASEKYDKRL I AQTKNVLKVLF LYIPLP MF WLF DQQGSRWIL QATTUDGDFGAM & 324 \\
\hline turkey & 270 & WASE KYDKRL I AQTKMVLKVLF L Y IPLP HF WALF DQ GGSRTL QATTMDGDFGAL & 324 \\
\hline zebrafish & 271 & WAE KYDKLLIMQVKMVVKVLFLYIPLP HF WALF DQGSRUTIQATIM GNF GGF & 325 \\
\hline
\end{tabular}




\begin{tabular}{|c|c|c|c|}
\hline a. cod & 271 & WADEKYE KLL IAQIKMVL KVLFL Y IPLPMF WTLFDQQSSRWTLQATTMD GDF GLL & 325 \\
\hline $\begin{array}{l}\text { icefish } \\
\text { carp f2 }\end{array}$ & $\begin{array}{l}190 \\
108\end{array}$ & 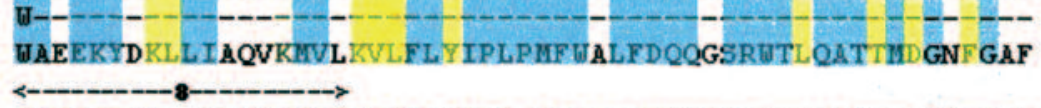 & 162 \\
\hline human & 319 & EIQPD QUQTVNA IL IV IMVP IF D AVL YPL I ARCGFNF TSLKKMAVGMVL ASMAFV & 373 \\
\hline rabbit & 319 & EIOPDQHOTVNTIL I I ILVP IMD AVVYPL IAKCGLNF TSL KKMT IGMFL ASMAFV & 373 \\
\hline rat & 319 & EIOPDQMOTVNAIL IVINVP IVD AVVYPL I AKCGFNF TSLKKMTVGMFLASHAFV & 373 \\
\hline mouse & 319 & EIOPDQHQTVNA ILNVNNGPNVD AVVYRS IAKCGFNF TSLKKMTVGMFLASMAFV & 373 \\
\hline sheep & 319 & EIQPDQHQTVNAIL IVVNVP IVD AVVYPL IAKCGLNF TSLKKMTVGMFL ASMAFV & 373 \\
\hline pig & 319 & KIQPDQMQTVNAIL IVIMVP IMD AVVYPL I AKCGLNF TSLRKMTVGMFLASMAFV & 373 \\
\hline dog & 319 & EVQPDQMQTVNAIL IVVMVP IMD AVVYPL I AKCGFNF TSLKRMTVGMFL ASMAFV & 373 \\
\hline chicken & 325 & QIQPDQMQTVNP IL I I IMVPVVD AVI YPL IQKCKINF TPLRRITVGMFL AGL AFV & 379 \\
\hline turkey & 325 & QIQP DQMQTVNP IL I I IMVPVVD AVI YPL IQKCK INF TPLRKI TVGMFL AGL AF I & 379 \\
\hline zebrafish & 326 & VIQPDQNQIVNP IL IVIMVP IMDSA I YPL IKLCRINF TPLRKYTVGIVLAAL AFV & 380 \\
\hline a. $\operatorname{cod}$ & 326 & VIQPDQMQTVNP IL ILGFVP IVDSV I YPL I AKCGLNF TPLKRMTVGMF MAAL AF I & 380 \\
\hline carp $\mathbf{f 2}$ & 163 & IIQPDOM- & 169 \\
\hline
\end{tabular}

Yellow-conservative sequences among fish species of PepT1 gene; Blue-conservative sequences among vertebrate species of PepT1 gene.

Similarity of amino acid sequences in various species with division into transmembrane domains

Table 6 and connecting loops

\begin{tabular}{|c|c|c|c|c|c|c|}
\hline \multirow{2}{*}{ Species } & \multicolumn{6}{|c|}{ Similarity of amino acid [\%] } \\
\hline & TM 518 aa & Loop 5/6 28 aa & TM6 19 aа & Loop 6/7 45 aa & TM 718 aа & Loop 7/8 37 aa \\
\hline Mammals $^{\mathrm{a}}$ & 100 & 64 & 74 & 71 & 89 & 78.5 \\
\hline Birds $^{b}$ & 100 & 96.5 & 95 & 98 & 100 & 97 \\
\hline Fishes $^{\mathrm{c}}$ & 100 & 78.5 & 84 & 46.5 & 78 & 86 \\
\hline Zebrafish/carp ${ }^{\mathrm{c}}$ & 100 & 89 & 88.5 & 80 & 94.5 & 94.5 \\
\hline All species & 72 & 46.5 & 63 & 44.5 & 61 & 75.5 \\
\hline
\end{tabular}

ahuman, Homo sapiens; rabbit, Oryctolagus cuniculus; rat, Rattus norvegicus; mouse, Mus musculus; sheep, Ovis aries; pig, Sus scrofa; dog, Canis lupus familiaris; ${ }^{b}$ chicken, Gallus gallus; turkey Meleagris gallopavo; ${ }^{\mathrm{c}}$ zebrafish, Danio rerio; icefish, Chionodraco hamatus; Atlantic cod, Gadus morhua.

It is noteworthy that considerable conservatism at the level of primary protein structure was observed mainly for transmembrane domain regions (Table 6), particularly in TM 5, while in connecting loops homology was much lower.

\section{DISCUSSION}

Peptide transporters (PEPT) are membrane proteins responsible for selective transport of small peptides across the intestine enterocyte membranes (Chen et al. 2005). Among them, PepT1 is present in the small intestine villi and is of key importance for absorption of protein hydrolysis products, particularly dipeptides and tripeptides. The PepT1 protein in higher vertebrates shows similar length to each other, usually about 700 amino acid residues (708 in human, 707 in rat, and 709 in mouse,) while in lower vertebrates it tends to be longer. The difference relates rather to the length of loops connecting transmembrane domains than the length of the domains themselves (Liang et al. 1995, Miyamoto 1996, Fei et al. 2000). Although no crystallographic structure of PepT1 protein is known, a probable model of PepT1 protein was created (Abramson et al. 2003, Huang et al. 2003) using appropriate software, and crystallography of similar transporter proteins of E. coli LacY (crystallized bound to the substrate), and GlpT (crystallized without a substrate). PepT1 shows an $\alpha$-helix structure, and consists of 12 functional transmembrane domains, nonlinearly distributed within the cell membrane. It seems that a hydrophilous cation $\left(\mathrm{H}^{+}\right)$transmembrane channel exists, through which dipeptides, tripeptides and free amino acids are transported (Meredith and Price 2006). Among the 12 domains, seven are directly involved in channel structure (domains 1, 3, 5, 7, 8,9 , and 10). In the present study, the in silico analysis revealed that domains 5,6 , and 7 were the most conservative, while connecting regions (loops) (except for the one connecting domains 7 and 8) were more variable. Particularly domain TM 5, which is responsible for regulation of the rate of substrate transport through the cation channel, showed high level of conservatism (72\%). It is similarly to the domains 6 and 7, which participate in initiation of substrate binding, and regulate the rate of their flow ( $61 \%$ and $63 \%$, respectively). It is worth mentioning that an important role of some amino acid radicals was observed in other vertebrates, such as Y167, R282, or W294, substitution of which considerably disturbed biological activity of PepT1 protein (Bolger et al. 1998). 
In the fragments of PepT1 protein analyzed in the present study these sites are identical as in other species. Concluding, we can assume that high homology of PepT1 gene at the DNA level, and conservative primary structure of PepT1 protein probably reflect PepT1 conservative function, the pattern of expression, or PepT1 level corresponding to the internal environment conditions. The obtained partial sequence of common carp PepT1 should allow to test this hypothesis in future studies.

\section{ACKNOWLEDGEMENTS}

The presently reported study has been financed by the Ministry of Science and Higher Education, Republic of Poland, in the frames of the grant No. 311030 32/ 2256.

\section{REFERENCES}

Abramson J., Smirnova I., Kasho V., Verner G., Kaback H.R., Iwata S. 2003. Structure and mechanism of the lactose permease of Escherichia coli. Science 301 (5633): 610-615. DOI: 10.1126/science.1088196.

Amberg J.J., Myr C., Kamisaka Y., Jordal A.-E.O., Rust M.B., Hardy R.W., Koedijk R., Rønnestad I. 2008. Expression of the oligopeptide transporter, PepT1, in larval Atlantic cod (Gadus morhua). Comparative Biochemistry and Physiology, Part B: Biochemistry and Molecular Biology 150: 177-182. DOI:10.1016/j.cbpb.2008.02.011.

Bolger M.B., Haworth I.S., Yeung A.K., Ann D., von Grafenstein H., Hamm-Alvarez S., Okamoto C.T., Kim K.J., Basu S.K., Wu S., Lee V.H. 1998. Structure, function, and molecular modeling approaches to the study of the intestinal dipeptide transporter PepT1. Journal of Pharmaceutical Sciences 87: 1286-1291. DOI: 10.1021/js980090u.

Chen H., Pan Y., Wong E.A., Bloomquist J.R., Webb K.E.jr. 2002. Molecular cloning and functional expression of a chicken intestinal peptide transporter (cPepT1) in Xenopus oocytes and Chinese hamster ovary cells. Journal of Nutrition 132: 387-393.

Chen H., Pan Y., Wong E.A., Webb K.E.jr. 2005. Dietary protein level and stage of development affect expression of an intestinal peptide transporter (cPepT1) in chickens. Journal of Nutrition 135: 193-198.

Fei Y.-J., Sugawara M., Liu J.-C., Li H.W., Ganapathy V., Ganapathy M.E., Leibach F.H. 2000. cDNA structure, genomic organization, and promoter analysis of the mouse intestinal peptide transporter PEPT1. Biochimica et Biophysica Acta - Gene Structure and Expression 1492: 145-154. DOI: 10.1016/S0167-4781(00)00101-9

Huang Y., Lemieux M.J., Song J., Auer M., Wang D.-N. 2003. Structure and mechanism of the glycerol-3-phosphate transporter from Escherichia coli. Science 301 (5633): 616-620. DOI: 10.1126/science.1087619.
Klang J.E., Burnworth L.A., PanY.X., Webb K.E.jr. Wong E.A. 2005. Functional characterization of a cloned pig intestinal peptide transporter (pPepT1). Journal of Animal Science 83: 172-181.

Liang R., Fei Y.-J., Prasad P.D., Ramamoorthy S., Han H., Yang-Feng T.L., Hediger M.A., Ganapathy V., Leibach F.H. 1995. Human intestinal $\mathrm{H}^{+}$/peptide cotransporter. Cloning, functional expression, and chromosomal localization. Journal of Biological Chemistry 270: 6456-6463. DOI: 10.1074/jbc.270.12.6456.

Maffia M., Rizzello A., Acierno R., Verri T., Rollo M., Danieli A., Döring F., Daniel H., Storelli C. 2003. Characterisation of intestinal peptide transporter of the Antarctic haemoglobinless teleost Chionodraco hamatus. Journal of Experimental Biology 206: 705-714. DOI: 10.1242/jeb.00145.

Meredith D., Price R.A. 2006. Molecular modeling of PepT1towards a structure. Journal of Membrane Biology 213: 79-88. DOI: 10.1007/s00232-006-0876-6.

Miyamoto K., Shiraga T., Morita K., Yamamoto H., Haga H., Taketani Y., Tamai I., Sai Y., Tsuji A., Takeda E. 1996. Sequence, tissue distribution and developmental changes in rat intestinal oligopeptide transporter. Biochimica et Biophysica Acta - Gene Structure and Expression 1305: 34-38. DOI: 10.1016/0167-4781(95)00208-1.

Pan Y., Wong E.A., Bloomquist J.R., Webb K.E. jr. 2001. Expression of a cloned ovine gastrointestinal peptide transporter (oPepT1) in Xenopus oocytes induces uptake of oligopeptides in vitro. Journal of Nutrition 131: 1264-1270.

Rønnestad I., Gavaia P.J., Viegas C.S., Verri T., Romano A., Nilsen T.O., Jordal A.E., Kamisaka Y., Cancela M.L. 2007. Oligopeptide transporter PepT1 in Atlantic cod (Gadus morhua L.): cloning, tissue expression and comparative aspects. Journal of Experimental Biology 210: 3883-3896. DOI: 10.1242/jeb.007898.

Van L., Pan Y.X., Bloomquist J.R., Webb K.E.jr., Wong E.A. 2005. Developmental regulation of a turkey intestinal peptide transporter (PepT1). Poultry Science 84: 75-82.

Verri T., Kottra G., Romano A., Tiso N., Peric M., Maffia M., Boll M., Argenton F., Daniel H., Storelli C. 2003. Molecular and functional characterisation of the zebrafish (Danio rerio) PepT1-type peptide transporter. Federation of European Biochemical Societies Letters 549: 115-122. DOI: 10.1016/S0014-5793(03)00759-2.

Received: 6 March 2009

Accepted: 3 June 2009

Published electronically: 10 December 2009 